\title{
David Orlović
}

Akvilejski prilaz 13, HR-52100 Pula

davidorlovic911@gmail.com

\section{Celebrating Empire. Organization of "General Assemblies of the Forces of the Regime" 1935-6 in Italy's Province of Istria}

Izvorni znanstveni rad | Original scientific paper

UDK 329.18(497.5-3 Istra)"1935/1936"

Primljeno | Received: 8. X. 2013.

\begin{abstract}
This article describes the preparation and execution of mass rallies in Italy's province of Istria, which had marked the beginning and the end of the Italian invasion of Ethiopia (October 1935 - May 1936). The events were organized throughout Italy, where millions of Italians assembled in public spaces in order to listen to the speeches of Benito Mussolini. On October $2^{\text {nd }} 1935$, the regime organized a "General Assembly of the Forces of the Regime" during which the beginning of the war had been announced, while on May $5^{\text {th }}$ and May $9^{\text {th }} 1936$ the victory and proclamation of the Empire was celebrated. Based on the presentation of these events via the writings of the official regime, the regime-affiliated press and confidential documents, the paper discusses the main organizational and ideological features of the mass rallies, with an emphasis on the manner in which the Fascist authorities prepared them and the way they were presented in the press. Modern historiography regards the Ethiopian War and the assemblies that accompanied it to be the pinnacle of the consensus given by the Italian people to the Fascist regime.
\end{abstract}

\section{Izvadak}

Članak opisuje pripremu i izvođenje masovnih skupova koji su označili početak i kraj talijanske invazije Etiopije (listopad 1935. - svibanj 1936.) u talijanskoj Istarskoj provinciji. Ti su događaji organizirani diljem Italije te su na njima milijuni Talijana dovedeni na javne prostore kako bi slušali govore Benita Mussolinija. Dana 2. listopada 1935. režim je organizirao „Opći skup režimskih snaga” na kojemu je najavljen početak rata, dok su 5. i 9. svibnja 1936. proslavljene pobjeda u ratu i 
uspostavljanje Carstva. Uz pomoć službenoga režimskog prikaza tih događaja kroz pisanje režimskoga tiska i povjerljivih dokumenata, rad tretira glavne organizacijske i ideološke odlike masovnih skupova, s posebnim osvrtom na način na koji su ih fašističke vlasti pripremile i predstavile u tisku. Suvremena historiografija Etiopski rat i skupove koji su ga pratili smatra vrhuncem u suglasnosti talijanskoga naroda s fašističkim režimom.

Key words: Ethiopian war, Fascism, Province of Istria, Pula, mass rallies, central organization

Ključne riječi: Etiopski rat, fašizam, Istarska provincija, Pula, masovni skupovi, organizacija iz središta

\section{Introduction}

The Italian invasion of Ethiopia between October 1935 and May 1936 is often seen as the climax of the period of consolidation of the Fascist regime in Italy. Although there was widespread scepticism towards the war in its initial stages, the economic sanctions imposed by the League of Nations the popularity of the fascist regime and the support for the war in Ethiopia at home had increased. The official Fascist propaganda celebrated incessant Italian victories in Ethiopia, parties were organized by the regime's organizations after every victory, not a single school course passed without mentioning the war, and newspapers were filled with ecstatic letters from the front. More specifically, in May 1936, after the Italian occupation of the Ethiopian capital Addis Ababa on May $5^{\text {th }}$ and the proclamation of the Italian Empire, the rebirth of the Empire "on the fateful hills of Rome" (sui colli fatali di Roma) on May $9^{\text {th }}$, are considered the pinnacle of a wide societal consensus achieved by the leadership of the Fascist regime. "Maybe for the first time in their lives, Italians wore their Fascist clothes without a sense of discomfort and their acclamations were spontaneous". ${ }^{1}$ With these words of caution the leading historian on Italian colonialism Angelo Del Boca follows his description of the euphoria generated in Fascist Italy in those days. Modern historiography regards the 1930s, which ended in a war, as a period of consolidation of the corporative Fascist state and a time which had forged a genuine "mass consent" around the figure of Benito Mussolini and his Fascist regime. ${ }^{2}$

This work focuses on the regime-organized mass rallies in Kingdom of Italy's Province of Istria related to the beginning and the end of the

1 Angelo Del Boca, Guerra d'Etiopia. L'ultima impresa del colonialismo, Milano 2010, 243.

2 Richard J. B. Bosworth, L'Italia di Mussolini, Milano 2009, 372. 
Ethiopian War (1935-36). The paper explores the manner in which the fascist authorities prepared these events and how they were presented in the press. The aim is to contribute to the existing knowledge about the Fascist regime's Ethiopian war-related consent-building operations and the war's impact on everyday life in Italy.

Hopefully, the thesis will contribute to the effort of reconstructing the political life in the Province of Istria and its connection to the political centre in Rome. Part of the wider Julian March (Venezia Giulia) region, annexed by Italy after World War I from the doomed Austro-Hungarian Empire, the Province was a contested border region. Since the majority of the population in the Province was non-Italian (roughly two thirds), the fascist totalitarian repression policies were different as compared to the rest of Italy, since they were oriented against Slavic speakers (Croats and Slovenes) in what many authors today call "Border Fascism". Thus, while in Italy proper fascist repression was oriented mostly against socialists, in the Julian March region (and thus Istria), oppression was used mostly as a tool of assimilation of the local Slavic speaking population, referred to by the authorities with the term allogeni. The word derives from Greek and means people of "other" [allo] "descent" [genos]. The names and surnames of the Slavs were Italianized, and all toponyms in the Province were given their Italian name variants. ${ }^{3}$

Like all other Italian Provinces, Istria was headed by the Prefect (prefetto) as well, while the various comuni (municipalities) in it had the podestà as the officials heading them. On the provincial level, the head of the National Fascist Party (Partito Nazionale Fascista) was the Federal Secretary (Segretario federale). The provincial capital of Istria was Pula (Italian: Pola, Slovenian: Pulj).

This research is based on the Corriere Istriano daily ${ }^{4}$ and confidential documents from the State Archive in Pazin, Croatia (Državni arhiv u

3 The most recent works dealing with the topic of Italian rule in Istria (1918-1943) are Darko Dukovski, Fašizam u Istri. 1918-1943 [Fascism in Istria 1918-1943], Pula 1998; Marina Cattaruzza, L'Italia e il confine orientale 1866-2006 [Italy and the Eastern Border 1866-2006], Milan 2007; and Herman Buršić, Od ropstva do slobode. Istra 1918-1945 [From Slavery to Freedom. Istria 1918-1945], Pula 2011.

4 The newspaper started with publishing in 1919 under the name of L'Azione, changing the name into Corriere Istriano in 1929. In the early period of the Fascist movement, the paper sided with Mussolini's ideology, only to later become the official voice of the regime in the Province of Istria. See: Marcello Bogneri, La stampa periodica italiana in Istria (1807 - 1947) [The Periodical Italian Press in Istria (18071947)], Trieste 1986, 111, 147. 
Pazinu). ${ }^{5}$ The views of the Slavic speaking population of Istria will be explored through their Zagreb-based émigré journal, the Istra. ${ }^{6}$

\section{Mass Rallies and the Ethiopian War: Fascistization through Apotheosis}

The Italian Fascist state was built as a single-party regime moving in the direction of a complete submission of the society, whose aim was to forge a "new man" devoted to the totalitarian and imperialist project of the governing party. The mass rallies as events of a public ritual should be seen as one of the main driving forces in the process of creating a totalitarian community and the fascistization of the masses, which fits into the approach of the eminent Italian historian Emilio Gentile to Italian Fascism as a project of gradual creation of a totalitarian state.

Various $19^{\text {th }}$ century thinkers and modern authors agree that the mass rallies as events of public ritual have the purpose of bringing about a cohesive feeling both among the individuals participating in such an event, as well as from the masses directed towards the state. ${ }^{8}$ The totalitarian states used these events for purposes of creating a "collective harmony" in a state of "perpetual mobilization" through constant education of the masses by the regimes, in the Italian case, a process called "fascistization" (fascistizzazione). ${ }^{9}$ The Fascist regime gave greater importance and even aesthetic value to the events of public ritual in Italy, exploiting the enthusiasm created by them and the cohesive effects for its purposes. The already existing rituals were "fascistized" in the process of connecting the State and the Party, and imposed strict rules on all public manifestations. ${ }^{10}$

Emilio Gentile argues that the "most grandiose events in the history of Fascist mass rituals were the vast assemblies which had happened during

5 The documents analyzed are from the Prefecture of Pola fundus of the archive, letters and telegrams between Rome and the Prefecture in Pola, as well as between Pola and the various Istrian localities.

6 Weekly journal in Croat and Slovene languages that was published between 1929 and 1940 in Zagreb (Kingdom of Yugoslavia) by Slavs that escaped from the Italian-ruled Julian March region. The author recently published a work on the topic of the coverage of the Ethiopian war by that journal: David Orlović, "La Guerra d'Etiopia e gli Slavi della Venezia Giulia sulle pagine dell'Istra, settimanale degli emigrati Croati e Sloveni a Zagabria", Quaderni del Centro di ricerche storiche di Rovigno, XXV, 2014, 177-220.

7 Constantin Iordachi, „Introduction“, in: Comparative Fascist Studies - New Perspectives, Constantin Iordachi (ed.), New York 2010, 33.

8 George L. Mosse, Masses and Man. Nationalist and Fascist Perceptions of Reality, Detroit 1987, 107; David I. Kertzer, Ritual, Politics and Power, New Haven - London 1988, 119.

9 Mabel Berezin, Making the Fascist Self: The Political Culture of Inter-war Italy, Ithaca 1997, 249; Emilio Gentile, The Sacralization of Politics in Fascist Italy, Cambridge - London 1996, 85.

10 Emilio Gentile, The Sacralization of Politics in Fascist Italy, 25-28, 88. 
the Ethiopian campaign". ${ }^{11}$ Historian Renzo De Felice argues that the fascistization process of the 20 s and early 30 s failed, and that the way to achieve the totalitarian nature of the regime was now implemented through foreign policy. ${ }^{12}$ The Italian foreign policy, which culminated in the Ethiopian War, unified the Italian people through the regime's exploitation of outside pressure for propaganda purposes. Throughout the war, mass rallies and events of public ritual contributed to the homogenization of the Italian people congregated in the squares around the country, culminating in May 1936 with assemblies celebrating Italy's victory, and nearing the closest state of unity with the Fascist regime. The aim of these mobilizations was to give the people "a focus of political love and emotion". ${ }^{3}$

The departure of soldiers and gatherings of people asking to be enrolled as volunteers in the campaign beginning with May 1935 kick-started a series of mass rallies that were re-occurring right up to the culmination of such events, when the official end of the war and the proclamation of the Italian Empire was marked by huge assemblies in early May 1936. Between these two periods, Istria, and thus the whole of Italy, saw a series of mass rallies, including the so-called "General Assembly of the Forces of the Regime" (Adunata generale delle forze del Regime) at the announcement of the start of the war on October $2^{\text {nd }}$, and the subsequent celebration of the takeover of the symbolic Ethiopian town of Adua on October $6^{\text {th }} 1935$. A period of stagnation in the campaign saw the regime using sanctions imposed by the League of Nations for propaganda purposes, rallying the masses to help the victimized country with a culmination in the "Day of Faith" (Giornata della fede) on December $18^{\text {th }} 1935$, which had a rehearsal on February $23^{\text {rd }}$ 1936. Early 1936 saw remembrance rallies celebrating the fallen soldiers from the Province in the colonial campaign with ceremonies of mostly religious character occurring on February $18^{\text {th }}$ and April $14^{\text {th }}$. At last, the return of victories in the Ethiopian battlefields meant that new reasons for mass rallies were created, so several Italian victories were celebrated in February and April 1936. Finally, early May 1936 saw several days of constant rallying and feasting, with masses gathering incessantly from May $5^{\text {th }}$ to May $10^{\text {th }}$ in order to mark the fall of the Ethiopian capital

11 Idem, "The Theatre of Politics in Fascist Italy", in: Günter Berghaus (ed.), Fascism and Theatre. Comparative Studies on the Aesthetics and Politics of Performance in Europe, 1925-1945, Providence - Oxford $1996,84$.

12 Renzo De Felice, Intervista sul fascismo, Michael A. Ledeen (ed.), Rome 1999, 69.

13 Berezin, Making the Fascist Self, 123. 
Addis Ababa and the proclamation of the Italian Empire. We see that in a span of a year, from May 1935 to May 1936, hardly a month had passed in Istria without a mass rally related to the war in Ethiopia. ${ }^{14}$

\section{The Adunata delle Forze del Regime of October $2^{\text {nd }} 1935$}

The "General Assembly of the Forces of the Regime" was preannounced on September $10^{\text {th }} 1935$ with the foglio d'ordine ("order sheet") n. $141 .^{15}$ In the early hours of October $2^{\text {nd }}$, Mussolini informed the King that the following day the Italian troops would start crossing the border of Italian Eritrea into the Empire of Ethiopia, and following the King's consent, the Duce prepared the communiqué n. 10 regarding the East African affairs to be spread through newspapers the following day, announcing that the military operations started. Contemporaneously with that, the Duce worked on giving the final touches to the speech that he meant to give in the afternoon" ${ }^{16}$ At 14.30 PM, from the microphones of the Italian radio broadcaster EIAR ${ }^{17}$, the Secretary of the Fascist Party Achille Starace announced that the signal for the adunata announced by the order sheet $n$. 141 would be given at 15.30 of the same day by the "sound of bells (...), siren screams and drum rolls" in various cities. In the words of the Italian historian Angelo Del Boca, after the signal was given, "in an event without precedents" over "twenty million Italians, largely in uniforms, headed towards the piazzas designated for the 'great concentrations'”. ${ }^{18}$

In Rome, Del Boca describes, the masses assembled at Piazza Venezia "in spite of bursts of rain". The Duce appeared on the usual balcony of his office at 18.45, and gave a speech which lasted eighteen minutes summarizing Italy's needs for colonial conquest - "to have a place under the Sun" after "thirteen years of Italy's wait to have its legitimate demands as a victorious nation fulfilled". ${ }^{19}$ After the speech, the crowds were "too excited to abandon the piazzas and occupied them until late that night while the speakers propagated fascist and patriotic songs". Del Boca adds that "in some cities processions marching under the lights of torches, while in

\footnotetext{
14 See: David Orlović, Constantly Mobilized. Mass Rallies in Fascist Italy during the 1935-36 Ethiopian War: Case Study Based on the Province of Istria, MA thesis, Budapest: Central European University, 2013.

15 Angelo Del Boca, Gli Italiani in Africa Orientale, II. La conquista dell'Impero, Milano 2001, 391.

16 Ibid.

17 Ente Italiano per le Audizioni Radiofoniche.

18 Del Boca, Gli Italiani in Africa Orientale, 391.

19 Ibid, 392.
} 
others puppets resembling the negus were put on fire”. ${ }^{20}$ Now, the paper will turn to the organization and the implementation of this adunata within the Province of Istria.

The 1935 September $21^{\text {st }}$ edition of the Corriere Istriano announced precise arrangements coming from the provincial Federal Secretary of the PNF Francesco Bellini for the adunata that was due soon. The detailed 17-point disposition included that the sign for the adunata would be given with three cannon shots, followed by drum rolls, sirens and bells, the orders for party members to leave their work places and quickly put on their fascist uniforms and gather at the selected places, orders for all of the fascist organizations (MVSN ${ }^{21}$, Balilla ${ }^{22}, \mathrm{GUF}^{23}$ etc.) to bring their pennants, as well as the order for the whole city to be wrapped in flags and illuminated. ${ }^{24}$

The September $22^{\text {nd }}$ edition of the Corriere Istriano gave additional details concerning the organization of the upcoming gathering. Now, precise orders were given to the members of the various fascist syndical organizations of Pula. Again, they were obliged to leave their work places immediately after the sound signal and to gather at Dante Alighieri square. This edition of the journal also included directives for the ex-combatants, the district group Vincenzo Ferrara, who were ordered to gather in the district headquarters on Diaz street, while the members of that group who owned motor vehicles were to be ready to participate in the adunata with their vehicles. Next, the members of the Bersaglieri units on leave were also ordered to gather at their local headquarters. Interestingly, the journal included directives for the farmers who were members of the Party. The marching band of the MVSN was asked to gather at its headquarters in Kandler Street, while the officers of the Balilla organization were specifically asked to be ready in "marching mode" with their belts and alpine hats. Finally, the members of the Fascio Femminile (female fascist organization) were asked to follow the orders pertaining to the male organizations listed above. The decrees note that “justified absences” (assenze giustificate) should

20 Ibid, 393.

21 Milizia Volontaria per la Sicurezza Nazionale, the regime’s paramilitary squads (Blackshirts).

22 Opera Nazionale Balilla, the youth organization established in 1926 responsible for the mobilization of support towards the Fascist regime of male children and adolescents. See "Youth Organizations", in: Historical Dictionary of Fascist Italy, Philip V. Cannistraro (ed.), Westport 1982, 569-573.

23 Acronym for the Gruppi Universitari Fascisti (Fascist University Groups), the regime organization mobilizing students ages 18-28. See Ibid.

24 "Precise disposizioni della Federazione Fascista", Corriere Istriano, September $21^{\text {st }} 1935,2$. 
be reported to the Provincial Secretariat of the organization in the very moment of the mobilization. ${ }^{25}$

Similarly, the September $24^{\text {th }}$ edition published arrangements regarding Istria's second biggest city, Rovinj (It. Rovigno). Beside the initial signal information, which included the sounding of the bells from local churches and the civic tower and the siren from the local tobacco factory, the various regime organizations had their rendezvous point set, like the Casa del Fascio, schools, the cinema etc. ${ }^{26}$

The public was expected to follow the calls of the gathering strictly with the aim to achieve maximum participation in the adunatas throughout the Province. The orders were intertwined with highly patriotic language that emphasized the people's participation in what was intended to be an event of greatest historical importance for the entire Nation. That is what was presented to the public through the media. It is, however, interesting to see what was happening behind the scenes, in the official structures of Istria and how the government in Rome saw the situation in the provinces, including Istria.

A telegram dated September $18^{\text {th }}$ and sent to Pula by the Ministry of the Press and Propaganda asked the Prefect of Istria to request the installation of speakers connected to radio devices in all important squares and localities of the Province before the date of September 22, explaining that the date chosen is "for technical reasons, and not because it is a date already set [for the adunata]". ${ }^{27}$ An undated telegram from Rome ordered the flagging and illumination of all public offices in the Province on the occasion of the announcement of the adunata. ${ }^{28}$

Another telegram, sent this time from the Minister of the Interior Buffarini to the Prefect of Istria on September $21^{\text {st }}$, set the guidelines for the working of the Prefecture headquarters in Pula and other public officials on the occasion of the adunata. The telegram requested the presence in the headquarters of the smallest possible number of personnel needed for the regular work of the body due to the fact that most of the employees

25 "Le disposizioni della Federazione Fascista per la mobilitazione delle forze del Regime", Corriere Istriano, September $22^{\text {nd }} 1935,2$.

26 "Dalla Provincia", Corriere Istriano, September $24^{\text {th }} 1935,4$

27 HR-DAPA (State Archive in Pazin), PP (Prefecture in Pula), 1935, b(ox): 281, f(ile): XVII-A-5-10/5 (Telegram regarding the installation of speakers).

28 HR-DAPA, PP, 1935, b: 281, f: XVII-A-5-10/3 (Telegram regarding the flagging and illumination of public offices). 
would have to participate in the gathering as members of the Fascist Party. Also, the Prefecture is ordered to send a telegraph "as soon as possible" the ministry of the Interior in Rome with the details about the performance of the adunata and the approximate number of participants, as well as to note any relevant emergency. ${ }^{29}$ Another telegram, dated September $24^{\text {th }}$, applied the same impositions regarding the keeping of a minimum number of employees at all public offices. ${ }^{30}$

The archival sources contain a document dated on September $23^{\text {rd }}$ compiled by the director of the main civilian hospital of Pula, Santorio Santorio, detailing the orders of how the employees of the hospital should behave, due to the fact that all the employees of that institution were asked to attend the adunata on the basis of the instructions of the Federal Secretary. The orders detail the erection of a first aid tent in the proximity of the Amphitheatre of Pula and the presence there of a couple of medics in case of any possible emergencies. Also, the manager of the power station of the hospital was allowed to stay at his post until his daily work ends. "To no other person working in the service of this institution will be considered justified the absence to the adunata (...) in conformity of the orders given by the respective hierarchies". In addition, the decree asks the non-members of the regime organization to gather in the atrium of the hospital, while some hospital officials present at the adunata were ordered to compile a list of the personnel present at the event before noon of the day following the adunata. ${ }^{31}$

A letter dated on the September $22^{\text {nd }}$ decreed that all the cinema halls were to be immediately closed in the Kingdom at the moment of the announcement in order to allow the public and the employees to take part in the adunata. The telegram specified the venues to be closed: the theatre Ciscutti, and the cinemas Umberto, Ideal, Arena, Garibaldi and Savoia. ${ }^{32}$

The authorities had in mind the possible disruptions of radio, telephone and telegraph operations in the Province in the event of the adunata and the participation of many employees. A message dated on September $18^{\text {th }}$ from the administration of the local Post and Telegraph operator reassured the Prefecture that all the operations would continue in full swing during the event of the adunata. ${ }^{33}$ A second message dated on the September

\footnotetext{
29 Idem, f: XVII-A-5-10/7 (1) (Telegram regarding the work of Prefecture officials).

30 Idem, f: XVII-A-5-10/7 (3) (Telegram regarding the work of public officials).

31 Idem, f: XVII-A-5-10/7 (2) (The Santorio Santorio hospital's director's orders).

32 Idem, f: XVII-A-5-10/8 (Letter regarding the closure of cinema halls).

33 Idem, f: XVII-A-5-10/5 (1) (Letter regarding the work of telephone offices).
} 
$26^{\text {th }}$ from the Prefecture in Pula sent to the Pula division of the Telephone Society of the Venezias (Società Telefonica delle Venezie) obliged the company that "in case of the summoning of the General Assembly out of the regular work time of the telephone offices of the Province, the employees should come immediately to the office and stay put until new orders are given". ${ }^{34}$

The official documents tell us that the preparations for the gathering were being taken seriously by both the central government in Rome, as well as the local authorities in the Province of Istria. The regime's aim to bring "twenty million" Italians to the piazzas was an order that could not be overlooked even in the tiniest corner of the country. One such example is the early announcement of the need for speakers and radios to be ready at public places. Also, organizations clearly had in mind the importance of the upcoming events and strictly abided by the orders of gathering, making all possible arrangements to allow the participation of its employees in the gatherings, as well as its continuation of work in the best possible way with minimum personnel available at the moment of the adunata. We may assume that the officials of lower rank wanted the organizations and bodies under their command to behave in line as much as possible with the government's aims in order to show their fidelity to Fascism.

The October $3^{\text {rd }}$ edition of the Corriere Istriano gives a detailed description of the events that took place in Pula the previous day. At 15.30 PM, cannon shots followed by church bells and the "scream" of sirens announced the beginning of the adunata. People of various age and gender "rushed towards their homes to wear their uniforms". The journal notes the bad weather with rain pouring the whole day, but the city was soon wrapped in Italian flags and half an hour later the people were ready at places prescribed for the gathering. Although the weather changed for the worse, "the enthusiasm reached the highest point humanly possible". ${ }^{35}$

The writer of the article calculated the fascists present as 25.000 of the Commune of Pula (city and surroundings) plus the thousands of citizens non-members of the various organizations who spontaneously joined the gathering. "An awesome, superb and unforgettable gathering, worthy of the Caesarian epoch", the writer concludes. ${ }^{36}$

34 Idem, f: XVII-A-5-10/5 (2) (Letter regarding the work of STV telephone offices).

35 "Tutto il popolo di Pola inquadrato nelle organizzazioni del Regime risponde con indomita fierezza all'appello del Duce", Corriere Istriano, October $3^{\text {rd }} 1935,3$.

36 Ibid. 
The journal informed its readers that the idea of having the old Roman Amphitheatre of Pula as a venue for the adunata was dropped because of the bad weather. Accordingly, the Fascist Federation thought about that possibility, and with "truly admirable regularity" the masses could reach the following closed venues: the city theatre Politeama Ciscutti, the Circolo Savoia, the Sala Umberto, the Casa Balilla and other places where the radios with loudspeakers were prepared in advance. According to the journal, this process of the gathering was accompanied by the playing of patriotic songs and hymns through loudspeakers, "which amalgamated hearts and spirits in a high ideal which outdid all possible estimates". ${ }^{37}$

With the impossibility to attend all the events at all the venues simultaneously, the editors of the journal chose to describe the events in the main venue, the Politeama Ciscutti. The theatre is described as being completely filled by people, with the leading fascists of the province and various regime organizations present, identified by their pennants and flags. As the Duce's speech was being waited for impatiently, the marching band of the Scuole $C R E M^{38}$ continuously played patriotic and fascist compositions. The Duce's speech was listened to with "emotion with no limit" and the people's "soul was stretched to better hear and understand the meaning of His words", reads the article in the Corriere Istriano. ${ }^{39}$

The gathering was followed by the masses' filling of the streets of Pula and engaging in several processions with the marching bands leading them. The patriotic songs and fascist hymns were repeated in a "spectacle of fabulous beauty, causing chills". The processions went through the Sergia, Kandler, Carrara streets and the Largo Oberdan Square, they came together at the Port'Aurea Square (Golden Gate, a Roman triumphal arch) where they slowly dispersed. Three cannon shots signalled the end of the gathering at 19.00 PM, but people continued to celebrate in the illuminated streets of the city. ${ }^{40}$

We see that the journal describes the adunata as happening in extreme order, in line with the preparations described before. In line with events throughout the country, the Corriere Istriano wanted to show that the $a d u$ -

\footnotetext{
37 Ibid.

38 Schools of the Corpo Reale Equipaggi Marittimi, the Italian navy infantry corps present in Pula's arsenal.

39 "Tutto il popolo di Pola inquadrato nelle organizzazioni del Regime risponde con indomita fierezza all'appello del Duce", Corriere Istriano, October $3^{\text {rd }} 1935,3$.

40 Ibid.
} 
nata of October $2^{\text {nd }} 1935$ was a high point in the history of Fascist Italy.

A short notice in the October $3^{\text {rd }}$ edition of the Corriere Istriano claimed that from all over Istria news arrived that the gathering of the forces of the Regime was successful, "giving motive to delirious manifestations of patriotism", adding that "(a) unified and strong Istria marches on the orders of the Duce". ${ }^{41}$ The October $5^{\text {th }}$ edition of the journal brought correspondences regarding the Gathering of the Regime Forces in the following Istrian towns: Rovinj, Piran (It. Pirano), and Vrsar (It. Orsera). The details about the events in each of these locations are repetitive. In Rovinj, the weather problems forced the participants to gather in several closed venues, too, like fascist premises, schools, theatre and cinema. In Piran, the masses ignored the bad weather and congregated in Tartini Square. In the small town of Vrsar, all of the gathered people filled the elementary school, where several radios were installed. The gathering ended with the masses filling the Egidio Grego main square of the small town. ${ }^{42}$

The descriptions of the events of October $2^{\text {nd }} 1935$ in the Province are shorter summaries of the main event described in the Province's capital, Pula. The events in each location are described in a repetitive fashion, but again with an emphasis put on the orderly happening of the gatherings and the euphoria of the people participating in it. The event happening in every corner of Italy, in the smallest communities, in the absolutely same fashion, is the proof of the centrally-organized adunata that aimed at the presence of millions of Italians in front of the radio speakers.

In accordance with the Interior Minister's earlier request to the Prefect to provide the details of the adunata, to give an approximate number of participants in it, and to note any possible disturbances,$^{43}$ the Prefect Cimoroni sent a telegram on the evening of October $2^{\text {nd }}$ noting that the adunata occurred in Pula and the Province "in maximum order amid delirious manifestations of enthusiasm that reached its pinnacle with the Duce's speech", adding that "although the bad weather raged everywhere", the participants in the adunata [in the Province] number one hundred and thirty thousand along the twenty five thousand in the capital [Pula]." The Prefect also notes that "no incident of the slightest importance occurred" ${ }^{44}$ 
Cimoroni's telegram completely reflects the writing of Corriere Istriano. The Prefect put an emphasis on the regular happening of the gathering in Pula, and the euphoric reception of the events by the masses, with an emphasis on the adoration of the Fascist leader. A possible conclusion is that the Prefect wanted to show to his superiors that the Province under his jurisdiction behaved in line with the regime's expectations, with him doing a perfect work.

\section{The "Radiant May": The Apotheosis and Creation of the Empire}

The victorious culmination of the Ethiopian War came in May 1936, called the "Radiant African May" (Maggio radioso africano), a play on the "Radiant May" of 1915, when Italy entered the First World War. In the late afternoon of May $5^{\text {th }}$, on the day of the capture of the Ethiopian capital, Addis Ababa, syrens and bells summoned the masses to Piazza Venezia in Rome to listen to the Duce's speech, and throughout Italy they were a signal for masses to listen to the radio broadcast through loudspeakers placed around main squares. With the event starting at early evening, "the Duce announced to the four hundred thousand Romans under his balcony and to more than thirty million Italians listening in every Italian square that 'Ethiopia is now Italian"”. ${ }^{45}$ Four days later, after the Grand Council of Fascism's decision of the granting of the title of emperor to king Vittorio Emanuele III, and the title 'Founder of the Empire' to Benito Mussolini, thus creating the Italian Empire, the events of May $5^{\text {th }}$ were repeated. That evening, Mussolini announced these decisions to an even more enthusiastic masses. The Duce's words that the "Empire reappeared on the fateful hills of Rome" is the most well-known leit-motif of the "Radiant May" of $1936 .{ }^{46}$

The issue of May $5^{\text {th }}$ of the Corriere Istriano published the regime's order sheet no. 153 containing the dispositions for a new grand adunata. The points included, as in the case of the October 1935 gathering, the sound signals that would announce the beginning of the event, decreed for which fascist organizations the participation was mandatory, and gave the Federal Secretaries the task to manage the events in their respective Provinces. The order sheet concluded that the Federal Secretaries should telegram to Rome the approximate numbers of participants. ${ }^{47}$ The Federal Secretary's

45 Emilio Gentile, Fascismo di pietra, Roma - Bari 2010, 124.

46 Ibid.

47 "Le disposizioni per la grande adunata", Corriere Istriano, May $5^{\text {th }} 1936,1$. 
detailed dispositions for the event in Pula were published in the same issue. The members of various organizations were asked to reach their respective headquarters at the issuing of the signal, only to join in the mass gathering at the Roman Amphitheatre of Pula, but took advance precautions in case of bad weather. ${ }^{48}$ The huge Roman-era monument dominating the city was planned to host the October $2^{\text {nd }} 1935$ adunata, but was not used on that occasion indeed because of bad weather. The May $5^{\text {th }}$ gathering was the first event connected to the empire-building Ethiopian campaign that was to happen in the Amphitheatre, often cited among the Italians as the symbol of the city's Romanity and Latin culture.

The archival material shows a hasty preparation but not less efficient when compared to the adunata of October $2^{\text {nd }}$ 1935. A telegram from the Ministry of Interior sent to all the Prefectures of the Kingdom, including Istria, decreed that the public officials should respond to the call for the latest gathering, while only the smallest possible number should stay at work to secure the continuity of operations. The telegram ordered the illumination and instalment of flags on public buildings, too. ${ }^{49}$ At the same time, a message from the Prefect to the commander of the Carabinieri division in the Province asked that "concise news via telegraph should be reported as soon as possible to me on the proceeding of the adunata (...) and communicate the approximate numbers of participants, as well as the weather conditions, while noting any emergency worthy mentioning." ${ }^{50}$

The signal for the gathering on May $5^{\text {th }}$ was given at 18.15 PM. After that, the streets became full of Fascists and non-party members, aiming to reach the Amphitheatre in orderly fashion:

"Roman and Fascist Pula, confused in an unique heartbeat of brotherly affection with all our armed forces, gave way to an impetus of exaltation, (...) directed towards the Duce who is going to give to Italy and the world the awaited announcement (...) of glory and victory." ${ }^{1}$

Two stages were prepared in the Amphitheatre in order to host the Province's leading officials and the pennants of the various fascist orga-

48 "Le disposizioni della Federazione Fascista", Corriere Istriano, May $5^{\text {th }} 1936,3$.

49 HR-DAPA, PP, 1936, b: 281, f: XVII-A-5-10/11 (3) (Telegram regarding the work of public officials on May $\left.5^{\text {th }} 1936\right)$.

50 Idem, f: XVII-A-5-10/11 (5) (Prefect's letter asking Carabinieri reports from localities in the Province).

51 "Trentamila persone hanno ieri acclamato all'Arena il Duce", Corriere Istriano, May ${ }^{\text {th }} 1936,3$. 
nizations of the city. Behind them speakers were installed and flags were hanged inside the Amphitheatre. Reflectors were soon lighted, "which often highlighted the large satirical billboards held by soldiers (...) on which the negus, [UK Foreign Secretary Anthony] eden [sic!] and associates appear in the most appropriate expressions." ${ }^{2}$

The mass listened to the Duce's speech crowded inside the ancient Roman monument. After its end, "the whole Arena, fantastically illuminated by the reflectors, seemed lighting up in a fiery ray". People started leaving the venue in order to form processions holding torches and Fascist pennants, which afterwards ended at the Forum. "After the historical ceremony of redemption [after World War I], the one from last night was certainly the most spectacular and enthusiastic that Pula ever saw". The newspaper counted the participants in this adunata as thirty thousand. ${ }^{53} \mathrm{~A}$ telegram sent from the Carabinieri corps of Pula to the Prefect's office gave the same number of participants in this adunata, also noting that the process of gathering of the people "took less than one hour to happen". The report reads that "After the melting away of the gathering maximized enthusiasm was noted, later becoming delirious, and after the end of the Duce's speech an unending procession took place, with singing of the hymns of the [Fascist] revolution through the streets of the city". ${ }^{54}$

The assembly of May $5^{\text {th }}$ occurred all around the Province of Istria, with the sound signals announcing the adunate. The Corriere reported on May $8^{\text {th }}$ that 7.000 people amassed in Rovinj, listened to the speech, and continued celebrating late into the night. The same event, without the number of participants, is described in the cities and towns of Piran, Oprtalj (It. Portole), Vižinada (It. Visinada), and Buzet (It. Pinguente), where a "promise made on the day of the takeover of Adua was maintained", with people offered free wine "that was, naturally, immediately assaulted and consumed in a flash" ${ }^{55}$ More details came in the edition of May $9^{\text {th }}$, with descriptions of the adunate in Vodnjan (It. Dignano), Umag (It. Umago), Višnjan (It. Visignano) and Fažana (It. Fasana). ${ }^{56}$ The celebrations in these communities followed the same pattern, since the events were controlled centrally.

\footnotetext{
52 Ibid.

53 Ibid.

54 HR-DAPA, PP, 1936, b: 280, f: XVII-A-5-10/1 (1) (Telegram on the adunata of May $5^{\text {th }} 1936$ in Pola).

55 "La grandiosa manifestazione in Istria in occasione del raduno del popolo italiano", Corriere Istriano, May $8^{\text {th }} 1936,3$.

56 "Dalla Provincia", Corriere Istriano, May $8^{\text {th }} 1936,4$.
} 
Indeed, the Carabinieri responded to the Prefect's request to be informed about the happenings throughout the Province. The brigade in the community of Cerovlje (It. Cerreto), central Istria, reported to the Prefect the regular gathering in the headquarters of the Dopolavoro, with three hundred people participating in it, "almost the totality of the inhabitants". The telegram notes the processions and illumination of buildings in the village, with "normal progress of celebration in other fractions under jurisdiction [of that unit]". ${ }^{57}$ From Tinjan (It. Antignana), the Carabinieri reported the "intervention of around 500 persons in ordinary manner, all enthusiastically applauding the Duce's speech" with "normal public order" ${ }^{58}$ In the northern city of Koper (It. Capodistria, Cr. Kopar), along with the emphasis of the participation of six thousand individuals and their "extolling of the King, the Duce and the glorious army", the Carabinieri reported "optimal weather conditions" during the adunata, as the Prefect had asked for in his decree. ${ }^{59}$

A longer message dated on May $8^{\text {th }}$ sent from the Podestà of the small locality of Oprtalj to the Prefect Cimoroni in Pula details the events of May $5^{\text {th }}$. The sender wrote that the adunata, "in spite of its announcement at the last moment", resulted in the participation of 1500 persons "from the Castle and [surrounding] County". The Podestà mentioned the "loud applauses" after the Duce's speech, which was followed by the performance of the Dopolavoro's marching band and by a religious ceremony in the town's church, while the windows were kept illuminated along with the "fires of joy in the fields". Also, the letter points out the fact that people from more distant villages kept arriving in Oprtalj later in the evening, when the gathering was slowly drawing to a close. ${ }^{60}$

Again, as in the case of the adunata of October $2^{\text {nd }} 1935$, both the press and the telegrams between Istrian officials do not avoid emphasizing the enthusiasm of the masses and its delirious reactions to the speech by Benito Mussolini. The regime again concluded that the event should regularly happen in the smallest parts of the country, regularly asking for confirmation from the local authorities. Telegram reports from the smaller communities went as far as to note the participation in the gathering of people residing

57 HR-DAPA, PP, 1936, b: 280, f: XVII-A-5-10/1 (2) (Telegram on the adunata of May $5^{\text {th }} 1936$ in Cerovlje).

58 Idem, f: XVII-A-5-10/1 (3) (Telegram on the adunata of May $5^{\text {th }} 1936$ in Tinjan).

59 Idem, f: XVII-A-5-10/1 (4) (Telegram on the adunata of May $5^{\text {th }} 1936$ in Koper).

60 HR-DAPA, PP, 1936, b: 281, f: XVII-A-5-10/11 (7) (Letter from the Podestà of Oprtalj regarding the gathering of May $\left.5^{\text {th }} 1936\right)$. 
in surrounding villages, who probably took hours to arrive to the centres of the various Comuni.

Further archival material shows Rome's aims to have the following days pass in a celebratory mode in all the Provinces of Italy, including Istria. A telegram sent from the Duce's office on May $5^{\text {th }}$ ordered the installation of Italian flags on public buildings on the days of May $6^{\text {th }}, 7^{\text {th }}$ and $8^{\text {th }}$ "from dusk to dawn" ${ }^{61}$ Another telegram decreed holiday working hours for public offices on May $6^{\text {th }} .^{62}$

Indeed, the following day of May $6^{\text {th }}$, was marked by constant feasting. The Corriere Istriano writes that students from the Magisterial Institute filled the squares and streets of Pula starting at early morning in order to continue the celebrations. The students, soon joined by high school pupils, formed a procession that visited government buildings in the city. In elementary schools, the journal writes, singing of hymns and patriotic songs was organized, followed by occasional speeches by the heads of these institutions. The Alessandro Manzoni school organized a visit to the Marine cemetery, where flowers were laid on the tombs of local Fascist heroes and those from the First World War. In the evening of the same day, bands played fascist and patriotic songs in Port'Aurea Square, while new processions were formed that continued late into the night. The description of the May $6^{\text {th }}$ events ends with the note that "popular joy was spontaneous and firm, giving the best example that the sentiments of the citizens of Pula were totalitarian and Fascist in nature." ${ }^{3}$

The Corriere Istriano writes that jubilation continued on May $7^{\text {th }}$, too, amplified by the news of the takeover of the Ethiopian town of Jijiga (Ogaden region) by the forces of general Rodolfo Graziani and by King offering to Mussolini a high military honour, the Medal of the military order of Savoy. The new assembly, the journal writes, was quickly organized by various regime organizations in the evening in front of the Casa del Fascio of Pula. A procession was formed and led by a marching band, while the public gathered along the streets where the procession passed, ending at Port'Aurea Square. There, amid loud acclamations, a local official read the

61 Idem, f: XVII-A-5-10/11 (1) (Telegram ordering the flagging of buildings following the takeover of Addis Ababa).

62 Idem, f: XVII-A-5-10/11 (4) (Telegram regarding the working hours of public offices following May $5^{\text {th }}$ 1936).

63 "Incontenibile esultanza della gioventù di Pola", Corriere Istriano, May $7^{\text {th }} 1936,3$. 
King's decision which honoured the Duce. After the assembly dissolved, the jubilation continued until late evening, the journal reports. ${ }^{64}$

The regime clearly aimed to have the people mobilized for several days after the May $5^{\text {th }}$ announcement, although the preparation for the gatherings those days was left to be organized by the individual local Fascist organizations in a more improvised manner.

The May $9^{\text {th }}$ edition of the Corriere Istriano carried a short notice calling the citizens of Pula to assemble at 22.00 PM at the Forum to listen to a new speech delivered by Mussolini. A second notice in the same issue decreed the illumination and flagging of public offices in the city. ${ }^{65}$ A telegram from the Prefect to the various Podestà around the Province decreed the instalment of loudspeakers in squares and other gathering locations for this event, too. ${ }^{66}$ The preparation of this event was again hasty, but the various Fascist organizations should certainly have been ready after several days filled with events and gatherings.

What followed was the "most solemn" of the evenings in this week of "Fascist passion", the Corriere writes. Largo Oberdan was "clad in black by the crowd", and "the families that had the privilege to own a radio, deserted their homes for the piazza in order to become protagonists of this highest moment that the Fascist Nation is living in". ${ }^{67}$ Regarding the decision not to use the Forum or Amphitheatre as a venue for this adunata, the journal notes that the local Fascist Federation saw the Forum as too small due to the large number of soldiers from the regular army asked to participate in the event, while the Amphitheatre was seen as difficult to be properly illuminated in such a short period of time. ${ }^{68}$ Interestingly though, the symbol of Pula's Romanity was not to be used for the event celebrating the reappearance of a new Roman Empire.

The Corriere counted the participants in this adunata in Pula as 40.000, noting that "even the Largo Oberdan proved itself too narrow, because when 40.000 citizens are mobilized, it is very difficult to find a good place in Pula to contain them all”. The Navy (Regia Marina) provided reflectors to be installed around the square. ${ }^{69}$

64 "Un'altra grandiosa manifestazione in onore del Duce", Corriere Istriano, May $8^{\text {th }} 1936,2$.

65 Corriere Istriano, May $9^{\text {th }} 1936,3$.

66 HR-DAPA, PP, 1936, b: 281, f: XVII-A-5-10/11 (6) (Prefect's telegram asking the installment of loudspeakers for the May $9^{\text {th }} 1936$ gathering).

67 “40.000 cittadini salutano l'avvento dell'Impero", Corriere Istriano, May $8^{\text {th }} 1936,3$.

68 Ibid.

69 Ibid. 
Before the speech by the Duce, the mass was able to hear both hymns played by the orchestra, as well as the chants from the people assembled in Rome, heard through the installed speakers in Pula. At 22.15, the radio announced that the Fascist Grand Council initiated its short proceedings, while at 22.35 the speech itself was announced. His words are described in the Istrian journal as "a new Gospel, going directly to the proud heart of every Italian”. After the speech, an army general left the tribune of honor to order the troops the hailing of the King, now Emperor and the salute to the Duce. It was the official end of the adunata. It was followed by processions through the city, this time using decorated lorries owned by the various Fascist organizations of the city. Again, the jubilation continued late into the night, the Corriere writes. At midnight, a new communiqué announcing the promoting of the victorious Italian commander in Ethiopia - Pietro Badoglio - to the title of Viceroy of Ethiopia, created further reasons for celebration, the journal notes. ${ }^{70}$

Announced in the Corriere's edition of May $8^{\text {th }}$, on the morning of Sunday May $10^{\text {th }}$ a Te Deum, a mass of thanksgiving for the victory in Ethiopia was organized in Pula's Forum. The orders from the Federal Secretary asked the members of various regime organizations to participate in it, while the officials representing the Armed forces would have a specially prepared "post of honour" at the ceremony. ${ }^{71}$ For the event, the journal on May $12^{\text {th }}$ described, the Forum was prepared with flags and torches, with an altar erected in front of the Temple of Augustus, the ancient Roman monument dominating the piazza. Under the arches of the Town Hall, mothers and widows of the combatants, from both the First World War and the latest African war, assembled. With them, the high Provincial officials, including the Prefect Oreste Cimoroni, were present. ${ }^{72}$

Immediately before the mass commenced, 101 cannon shots were fired. After the religious ceremony, the parroco of Pula, Monsignor Angeli delivered a speech praising the victory "by Italy's soldier" in Africa in face of the economic siege by the League of Nations. The speech ended with thanks to God for allowing the victory to happen. After his speech, the local casualties in the Ethiopian campaign were remembered through the reading of their names. After the ceremony, the Corriere writes, all the women mem-

71 “Il 'Te Deum' per la vittoria in A. O.”, Corriere Istriano, May $8^{\text {th }} 1936,2$.

72 "La solenne cerimonia religiosa al Foro Romano", Corriere Istriano, May $12^{\text {th }} 1936,3$. 
bers of the Fascio Femminile formed a procession that marched to the statue of the Roman emperor Augustus in front of the Amphitheatre, where an official placed a wreath "in homage to the founder of the Roman Empire". ${ }^{3}$ It is interesting to see how this event had the Catholic, Fascist religious elements joined together, with the element of Romanity present in the choosing of the place for the ceremony. The altar for the mass was put in front of the Temple of Augustus, the religious ceremony was followed by the Fascist rite for the fallen, and the dedication to Augustus concluded the event.

The Corriere Istriano edition of May $12^{\text {th }}$ described how the events of May $9^{\text {th }}$ happened in the Province, in the towns of Piran, Pazin, Vodnjan, Rovinj and Premantura (It. Promontore). Again, the same pattern: after the Duce's speech, processions amid singing and joyful acclamations were lauded. The Corriere described all the events after May $5^{\text {th }}$ in Rovinj, where the Salesian band played every evening between May $6^{\text {th }}$ and $8^{\text {th }}$. The Te Deum that was described in Pula on Sunday, May $10^{\text {th }}$, happened in each of these localities, too. ${ }^{74}$

To conclude this part, the long letter that the Podestà of the Comune of Vižinada sent to the Prefecture in Pula detailing the feasting throughout early May will be useful. The May $5^{\text {th }}$ celebration, the Podestà wrote, involved the participation of the inhabitants of many surrounding villages along the Fascists and many citizens of Vižinada, in a "participation so totalitarian, not seen even at time of the celebration of the annexation of this Commune to Italy [after World War I]". He detailed the listening to the Duce's speech in the main square, which was followed by a "mighty" procession that passed through the centre of the town "amid manifestations of joy". This gathering, the Podestà concludes, involved the participation of four thousand people. ${ }^{75}$

The description of the events follows with the mentioning of a religious ceremony which took place in the local church on the evening of May $6^{\text {th }}$. This event, too was followed by processions which lasted "until the early morning of the day 7 ", the letter sender underscores. ${ }^{76}$

The May $9^{\text {th }}$ gathering is also described, with an interesting note expressed by the Podestà: the event was attended by the "allogeni from the

73 Ibid.

74 "Dalla Provincia", Corriere Istriano, May $12^{\text {th }} 1936,4$.

75 HR-DAPA, PP, 1936, b: 281, f: XVII-A-5-10/11 (9) (Letter from the Podestà of Vižinada regarding the patriotic manifestations).

76 Ibid. 
most distant villages with their wives and children”. This is the first time that we find the mention of the Slavic element in Istria in the official documents related to the gatherings during the war in Ethiopia. The overall gathering that held the Duce's speech as a central point, the Podestà writes, was "welcomed with an enthusiasm never met before", and was followed by huge processions that continued until $3 \mathrm{AM}^{77}$

The letter emphasizes the fact that every evening had some form of joyous manifestations, "culminating" with May $10^{\text {th }}$, when a gathering organized by the Podestà himself that afternoon had the role to "crown with a demonstration under the light of the Sun the week consecrated to Victory and the Empire." The event involved speeches by him and the local priest, the Podestà continues, while the main focus were the wives and relatives of soldiers from Vižinada that were currently in Africa. A further event took place the following day, when all the schools of the Commune had the Duce's speeches repeated by the teachers, with new processions following the lectures. ${ }^{78}$ The Podestä's letter ends with the note that "(d)uring the period of assemblies, meaning from the $5^{\text {th }}$ to the $10^{\text {th }}$ [of May] all the houses were embellished with the tricolour flag, and in the evening the balconies of the houses were gorgeously illuminated. With the work of the Fascio Giovanile there were fires lit in the church tower, on the four columns of the communal cistern and on S. Tomaso hill."79

There is no doubt that the Podestà clearly wanted to show his efficient lead of the events in his Commune, clearly seen in his boasting of the event he personally organized on May $10^{\text {th }}$ which involved a speech that he delivered. He detailed every single event, wanting to show it followed the same pattern as in the rest of the country. The local element, involving the emphasis on the participation of the wives and relatives of soldiers sent to Africa took a prominent role only in the event organized by the Podestà. And again, the fact that he mentioned the participation of the Slavs arriving from distant villages is interesting in itself, although we currently cannot confirm his claims or see under which circumstances they attended, if they did: perhaps under police pressure?

That is, indeed, what Slovene and Croat contemporary sources suggest. The émigré journal of Istrian Slavs from Zagreb (Yugoslavia), the Istra, 
described a completely different reality in the backdrop of the celebrations. In the context of narrating the Fascist repression against the Slavs in the Julian March, the journal reported that surveillance was heightened during this period and the spy network investigated their behaviour during the celebrations. According to it, villagers had to abruptly finish their work in the fields when the signal for gathering was given and forced to attend the assemblies, while some were physically assaulted for not showing importance to the celebrations. ${ }^{80}$ An article even points out the fact that some Slavs who did not attend the gatherings suffered beatings and were forced to drink castor oil, while it was noted that there have been attacks on those who did not hang the Italian flags on their windows. ${ }^{81}$

\section{Conclusion}

The mass rallies in Istria that this research covered, and thus Fascist Italy in general, should be seen as one of the driving forces in the process of creating a totalitarian community and the fascistization of the masses, fitting into Emilio Gentile's approach to Italian Fascism as a project of gradual creation of a totalitarian state. The regime used these events for purposes of creating a "collective harmony" and a state of "perpetual mobilization" in the ongoing education of the masses. Throughout the Ethiopian war, the speeches of the Duce, mass rallies and other events of public ritual aimed at the homogenization of the people and for channelling their emotions towards the war in progress. Indeed, agreeing with most scholars, it can be argued that the gatherings during the Ethiopian war were both a cause and a result of the climax in consensus the regime achieved during the period.

The country-wide preparations for the "General Assembly of the Forces of the Regime" (Adunata generale delle forze del regime) that marked the beginning of the Italian invasion of Ethiopia on October $2^{\text {nd }} 1935$ were strictly implemented in the Province of Istria in line with the regime's expectations, and the general population was urged to participate in the mass demonstrations that were believed to have been marking the events of utmost historical significance. The preparations for the "Gathering", starting several weeks in advance, kept in mind the most minimal detail, ensuring the participation of every Fascist Party member, while the local daily

80 „Po zavzetju Adis Abebe“, Istra, May $15^{\text {th }}$ 1936, 1.

81 „Prisiljena proslava ob zavzetju Adis Abebe“, Istra, May $22^{\text {nd }} 1936,2$. 
journal Corriere Istriano galvanized the wide masses for this huge event. The gatherings in the so-called "Radiant African May" (Maggio radioso africano) period in Istria formed an incessant period of mobilization and celebration from May $5^{\text {th }}$ (after the announcement of the capture of the Ethiopian capital Addis Ababa) up to May 10 ${ }^{\text {th }}$ (after the proclamation of the Empire). In contrast to the initial grand adunata on October $2^{\text {nd }} 1935$, these gatherings were hastily prepared but were again ideologically organized and controlled from the government's centre in Rome. Two main gatherings (May $5^{\text {th }}$ and May $9^{\text {th }}$ ) included the listening to Mussolini's speeches through speakers put in public places, one of which had the huge Romanera Amphitheatre in Pula as a venue. The events happened in the whole Province, and local police were asked to report to the Prefecture in Pula in detail about events on each locality.

\section{Summary}

The author describes the preparation and implementation of mass rallies marking the beginning and the end of the Italian invasion of Ethiopia (October 1935 - May 1936) in Italy's province of Istria. Relying on official regime representation of these events through the writing of the regime-affiliated press and confidential documents, the paper discusses the main organizational and ideological features of the mass rallies, with an emphasis on the manner in which the fascist authorities prepared them and the way they were presented in the press. Throughout the war, mass rallies and events of public ritual contributed to the homogenization of the Italian people, culminating in May 1936 with oceanic assemblies celebrating the victory, and achieving the closest state of unity of the people with the Fascist regime.

The country-wide preparations for the "General Assembly of the Forces of the Regime" (Adunata generale delle forze del regime) that marked the beginning of the Italian invasion of Ethiopia were strictly implemented in the Province of Istria in line with the regime's expectations, and the general population was urged to participate in the mass demonstrations that were believed to have been marking the events of utmost historical significance. The preparations for the Assembly went to the minimal detail, ensuring the participation of every Fascist Party member in the event, while the local daily journal Corriere Istriano motivated the wide masses for this huge event. The Gathering took place in the late afternoon of October $2^{\text {nd }} 1935$, and both archival documents and the press (focusing on the provincial capital of Pula) emphasized the alleged utmost euphoria and enthusiasm that the event provoked, especially in its dimension of adoration of the Italian leader Benito Mussolini.

The gatherings in the so-called "Radiant African May" (Maggio radioso africano) in Istria in 1936 formed an incessant period of mobilization and celebration from May $5^{\text {th }}$ (after the announcement of the capture of the Ethiopian capital Addis 
Ababa) up to May $10^{\text {th }}$ (after the proclamation of the Empire). In contrast to the initial grand adunata on October $2^{\text {nd }} 1935$, these gatherings were more hastily prepared but were again ideologically organized and controlled from the government's centre in Rome. Two main gatherings (May $5^{\text {th }}$ and May $9^{\text {th }}$ ) involved the listening to Mussolini's speeches through speakers put in public places, one of which was the huge Roman-era Amphitheatre in Pula. Besides that, the gatherings followed an already established pattern of forming processions and playing music that captivated the people gathered until early morning hours. The events occurred in the whole Province, and local police were asked to report to the Prefecture in Pula in detail about the gatherings on each locality.

\section{Proslavljanje Carstva. Organizacija „Skupova režimskih snaga” 1935. - 1936. u talijanskoj Istarskoj provinciji}

\section{Sažetak}

Autor opisuje pripremu i izvođenje masovnih skupova koji su označili početak i kraj talijanske invazije Etiopije (listopad 1935. - svibanj 1936.) u Istarskoj provinciji. Uz pomoć službenoga režimskog prikaza tih događaja kroz pisanje režimskoga tiska i povjerljivih dokumenata, rad tretira glavne organizacijske i ideološke odlike masovnih skupova, s posebnim osvrtom na način na koji su in fašističke vlasti pripremile i predstavile u tisku. Tijekom rata masovni skupovi i događaji javnoga rituala doprinijeli su homogenizaciji Talijana, s vrhuncem u svibnju 1936. i masovnim skupovima u znak proslave pobjede te postizanja najtješnjega jedinstva naroda s fašističkim režimom.

Pripreme širom države za "Opći skup režimskih snaga” (Adunata generale delle forze del regime), koji je označio početak talijanske invazije Etiopije, bile su strogo provođene u Istarskoj provinciji u suglasnosti s očekivanjima režima, dok je javnost bila poticana da sudjeluje u masovnim demonstracijama za koje se vjerovalo da su obilježavale događaje od najveće povijesne važnosti. Pripreme za Skup vodile su računa o najmanjim detaljima osiguravši sudjelovanje svakoga člana Fašističke stranke u njemu. Lokalni dnevni list Corriere Istriano motivirao je široke mase za ovaj veliki događaj. Skup se odvio 2. listopada 1935., a arhivski dokumenti i tisak (s posebnim osvrtom na provincijsko sjedište Pulu) naglašavaju navodnu krajnju euforiju i entuzijazam koje je događaj uzrokovao, pogotovo u onom segmentu u kojemu je posrijedi bilo obožavanje talijanskoga Vođe Benita Mussolinija.

Skupovi tijekom tzv. „Sjajnoga afričkog svibnja” (Maggio radioso africano) u Istri 1936. činili su neprekidno razdoblje mobilizacije i slavlja od 5. svibnja (nakon objave zauzeća etiopske prijestolnice Adis Abebe) do 10. svibnja (nakon uspostave Carstva). Za razliku od prvotnoga velikog skupa 2. listopada 1935., ovi su skupovi mnogo užurbanije pripremljeni, ali ponovno ideološki organizirani i kontrolirani iz režimskoga središta u Rimu. Dva glavna skupa (5. i 9. svibnja), od kojih je jedan održan u rimskom Amfiteatru u Puli, uključivala su slušanje Mussolinijeva govora preko zvučnika postavljenih na javnim mjestima. Uz to, skupovi su pratili već uobičajen obrazac organiziranja procesija i sviranja glazbe koji je zadržavao ljude okupljenima do ranojutarnjih sati. Događaji su se odvili u cijeloj Provinciji te je lokalnim 
policijskim postrojbama bilo naređeno da detaljno obavijeste Prefekturu u Puli o skupovima u svakom naselju.

\section{Celebrando l'Impero. Organizzazione delle "Adunate delle Forze del Regime" nel 1935-36 nella provincia italiana d'Istria}

\section{Riassunto}

L'autore descrive i preparativi e lo svolgimento dei raduni di massa che hanno segnato l'inizio e la fine dell'invasione italiana dell'Etiopia (ottobre 1935 - maggio 1936), in questo caso quelli tenutisi nella Provincia d'Istria. Con l'aiuto della versione ufficiale del regime su tali avvenimenti che traspare dai contenuti della stampa del regime e dai documenti confidenziali, questo articolo tratta le caratteristiche organizzative ed ideologiche dei raduni di massa, con particolare attenzione al modo in cui il governo fascista li preparava e presentava nella stampa. Durante la guerra, i raduni di massa e gli eventi di rituale pubblico hanno favorito l'omogeneizzazione degli italiani, in maniera particolare nel maggio del 1936 con i raduni di massa in occasione dei festeggiamenti della vittoria e il conseguimento di una forte unità del popolo con il regime fascista.

I preparativi effettuati in tutto lo stato in occasione dell'"Adunata generale delle forze del regime", che ha segnato l'inizio dell'invasione italiana dell'Etiopia, sono stati eseguiti in maniera rigorosa anche nella Provincia d'Istria, in sintonia con le aspettative del regime, mentre la popolazione era stata esortata a partecipare alle dimostrazioni di massa, reputate quale tratto distintivo degli avvenimenti di grande rilevanza storica. I preparativi dell'Adunata tenevano conto dei minimi dettagli, assicurandovi la partecipazione di ciascun membro del Partito fascista. II giornale locale Corriere Istriano ha motivato le masse a partecipare a questo evento. L'Adunata si è tenuta il 2 ottobre 1935, e i documenti d'archivio e la stampa (interessati particolarmente alla sede provinciale di Pola), enfatizzano una presunta estrema euforia e l'entusiasmo provocati dall'evento, specie nel tratto riferito all'adorazione del Duce Benito Mussolini.

I raduni tenutisi durante il cosiddetto "Maggio radioso africano" nel 1936, in Istria erano costituiti da un periodo prolungato di continue mobilizzazioni e festeggiamenti durati dal 5 maggio (dopo l'annuncio della conquista della capitale etiopica di Adis Abeba) al 10 maggio (dopo la fondazione dell'Impero). A differenza del primo grande raduno del 2 ottobre 1935, questi incontri furono preparati in maniera molto più frettolosa, ma sono sempre ideologicamente organizzati e controllati dalla sede del regime di Roma. I due raduni principali (del 5 e del 9 maggio) includevano l'ascolto della trasmissione del discorso di Mussolini mediante gli altoparlanti collocati nei luoghi pubblici, uno dei quali si è svolto nell'Anfiteatro romano di Pola. Inoltre, i raduni erano accompagnati dall'usuale schema di organizzazione delle processioni e dalla musica, che intrattenevano la gente fino alle ore piccole. Tali eventi si sono svolti in tutta la Provincia e le forze di polizia locali avevano ricevuto l'ordine di informare dettagliatamente la Prefettura di Pola sui raduni tenutisi in ciascun abitato. 